\title{
Cell size and Varroa destructor mite infestations in susceptible and naturally-surviving honeybee (Apis mellifera ) colonies
}

\author{
Melissa A. Y. Oddie ${ }^{1}$, Peter NeumanN ${ }^{2,3}$, Bjørn Dahle ${ }^{4,5}$ \\ ${ }^{1}$ Department of Ecology, Swedish University of Agricultural Sciences, Uppsala, Sweden \\ ${ }^{2}$ Institute of Bee Health, Vetsuisse Faculty, University of Bern, Bern, Switzerland \\ ${ }^{3}$ Agroscope, Swiss Bee Research Center, Bern, Switzerland \\ ${ }^{4}$ Department of Animal and Aquacultural Sciences, Norwegian University of Life sciences, Ås, Norway \\ ${ }^{5}$ Norwegian Beekeepers Association, Kløfta, Norway
}

Received 24 November 2017 - Revised 31 May 2018 - Accepted 4 October 2018

\begin{abstract}
The ectoparasitic mite Varroa destructor is a key threat for European honeybee subspecies (Apis mellifera ) globally. However, some A. mellifera populations are known to survive mite infestations by means of natural selection (naturally surviving), likely due to reduced mite reproductive success. The effect of small brood cell size on mite reproductive success has not been investigated in these surviving populations and we have little knowledge of its relationship with mite-surviving traits. Here we tested the impact of smaller worker brood cell size on mite reproductive success in susceptible and naturally surviving colonies in Norway. The data show that mite reproductive success was significantly reduced in smaller cells in susceptible colonies (higher rates of nonreproduction, delayed reproduction, and male absence), but not in the surviving colonies. The results support the claim that smaller cell size can have an impact on $V$. destructor reproductive success, but this seems not to work in tandem with mite-surviving mechanisms favored by natural selection.
\end{abstract}

Apis mellifera / cell size / honeybee / Varroa destructor

\section{INTRODUCTION}

There is consensus that the ectoparasitic mite Varroa destructor is at present the most impactful global influence on the health of managed honeybees (Apis mellifera) of European origin (Dahle 2010; Genersch et al. 2010; Neumann and Carreck 2010; Rosenkranz et al. 2010; VanEngelsdorp et al. 2011). This invasive Asian mite carries out its entire reproductive cycle within the capped brood cells of the honeybee host, exposing both adults and juveniles to infestations (Rosenkranz et al. 2010). Since its invasion, this mite has become a potent vector for a number of viruses and altered the virulence of

Corresponding author: M. Oddie, melissa.oddie@slu.se

Manuscript editor: Yves Le Conte some pathogens to the point where they have become a lethal problem (Martin 2001; Chen et al. 2006; Dainat et al. 2012). Generally, colonies of European honeybee subspecies have no effective defense against the mite and parasite populations generally increase at an exponential rate until colonies collapse under viral pressure within 2 to 3 years (Sammataro et al. 2000; Rosenkranz et al. 2010; Dainat et al. 2012).

At present, beekeepers use a range of acaricides, which can often result in the development of resistance in the mite, contamination of bee products, and undesired side effects on the bees themselves (reviewed by Rosenkranz et al. (2010). Regular mite treatments also prevent adaptation to the selection pressure of this novel parasite (Neumann and Blacquière 2017). Indeed, over the past 17 years, several distinct, untreated populations of European 
honeybee subspecies have been documented to survive $V$. destructor infestations due to natural selection (Fries et al. 2006, Le Conte et al. 2007, Seeley 2007, Locke et al. 2012; Mikheyev et al. 2015; Oddie et al. 2017, reviewed by Locke 2016). The means by which they achieve this is likely their ability to reduce $V$. destructor reproductive success by approximately 30\% (Locke 2016; Oddie et al. 2017). A number of mechanisms have been put forward as contributors to such reduced mite reproductive success (Rinderer et al. 2001; Salvy et al. 2001; Harris et al. 2010; Locke et al. 2014; Oddie et al. 2018). Among these, the reduction of cell size has been proposed as an effective solution that beekeepers can employ. It is hypothesized that a smaller cell size limits the number of foundresses that can invade a cell and makes it difficult for mites to move within, a necessary action throughout the reproductive process. It may also increase instances of entrapment, where the mite is pinned between the brood cell wall and the silk cocoon spun by the pupating larvae, effectively immobilizing and ultimately killing the foundress, preventing reproduction entirely. As a natural trait, a smaller cell size has been found in the surviving African and Africanized A. mellifera populations; however, as a mechanical method of controlling $V$. destructor managed by European beekeepers, evidence has been mixed, with studies supporting (De Jong and Morse 1988; De Ruijter and Calis 1988; Message and Gonçalves 1995; Piccirillo and De Jong 2003; Maggi et al. 2010) and refuting the effect (Ellis et al. 2009; Taylor et al. 2008; Berry et al. 2009). Aside from this ambiguity, interactions with other surviving mechanisms have not yet been thoroughly investigated: Small cell size can increase honeybee responsiveness to certain hygienic tests, such as the example provided by Olszewski et al. (2014); bees on small cell size tended to remove pin-killed brood faster than bees on a larger cell size Though known surviving African/ized populations have a smaller cell size, the role small cell size plays in populations of naturally-surviving European honeybees is currently not known. Interestingly, colonies of the recently documented Norwegian surviving population (Oddie et al. 2017) were selected for resistance while on a comb foundation cell size of $4.93 \mathrm{~mm}$, smaller than the conventional size of $5.3 \mathrm{~mm}$. This population did not display higher levels of grooming or mite-targeted brood removal, but the observed reduction in reproductive success was evidently due to a brood care behavior termed "cell recapping" in which cells during pupal development (and mite reproduction) were opened, exposing them to changes in temperature and humidity (Oddie et al. 2018). Our study is aimed at comparing the impact of small cell size between naturally-surviving honeybees and their susceptible counterparts. We intend to analyze mite reproductive success in a depth not commonly used by previous studies on cell size. Given that small cell size may play a significant role in reducing mite reproduction, we expect that manipulating the cell size will yield effects on mite reproductive success in both surviving and susceptible colonies and may act synergistically with the adult-mediated trait present in surviving colonies.

\section{METHODS}

The experiments were conducted in the Oslo region of Norway. In order to track the interaction of cell size and the surviving phenotype in the surviving population, 10 local susceptible queenright $A$. mellifera colonies from a donor apiary were chosen for their high $V$. destructor mite infestation rates $(\sim 10-50 \%$ brood infestation), this was done to ensure sufficient mites were available to conduct the study as the surviving population yielded consistently low mite numbers and brood infestation rates over several years. Two brood frames from each donor colony were distributed among the colonies in two separate apiaries $50 \mathrm{~km}$ apart. The first receiver apiary contained only local $V$. destructor susceptible stock, reared on a standard large brood cell size (wax foundation size $5.3 \mathrm{~mm}$ ). Grooming and mite-targeted brood removal were not found at any significant level (Oddie et al. 2017). The second receiver apiary contained bees of a local surviving stock (Oddie et al. 2017). These bees were reared on the small cell size used in this study (wax foundation size $4.93 \mathrm{~mm}$ ) and they too did not display high levels of the aforementioned adult bee behaviors. Five colonies in each receiver apiary were chosen randomly to take one frame of each of the two foundation base sizes. Prior to the swap, each donor colony was provided with one frame of large cell comb $(5.3 \mathrm{~mm})$ and one frame of small cell comb 
(4.93 mm). Small cell size frames were built out by the bees that had been reared on the small comb size to obtain an accurate "actual" cell size. This was done because bees reared on larger cells build out small comb much less accurately (Taylor et al. 2008). Queens were caged on built frames for a period of $48 \mathrm{~h}$. Brood was left in the donor colonies for 9 days until just after the capping phase (Dietemann et al. 2012) and then transferred to the receiver apiaries. Frames were kept in receiver colonies for a period of 10 days, allowing enough time for honeybee brood to develop and juvenile mite stages to mature to a point where mite reproduction could be properly measured (Martin 1995; Dietemann et al. 2012). Frames were then removed and stored at $-20^{\circ} \mathrm{C}$ until cells could be dissected. Brood cells were opened in a horizontal line beginning in the middle of the brood patch and skipping three rows progressively above and below each previously examined line to ensure even sampling across the patch. Bee brood was aged according to Martin (1995) and measured in stage instead of exact age because the exact age of brood could not be guaranteed. Mite stages were identified using the ontogenetic developmental chart by Martin (1995) and recorded for each cell. Multiple foundress events were included in the analysis of viable female offspring because our interest lay in the overall reproductive success of the mite population on each frame rather than success of the individual. Moreover, the number of foundresses also had the potential to interact with cell size. For the binary measures of reproductive success (i.e., delayed reproduction, non-reproduction, and male presence), only cells containing a single foundress were included, as multiple foundresses in a cell make these parameters impossible to determine accurately. Using the brood and mite stage, we were able to determine the average number of viable female offspring produced per foundress and whether each foundress in a single-infested cell was displaying delayed mite reproduction (retarded production of viable female offspring), nonreproduction (failure to produce viable female offspring), and infertility (no offspring). Male mite presence was recorded as well as the number of foundresses in each cell. The measure of viable female mite offspring was defined as the number of female offspring that had the potential to emerge successfully given an appropriate stage of the brood and was in a cell that also contained a male (Corrêa-Marques et al. 2003; Locke et al. 2012). Taylor et al. (2008) found that the actual cell size drawn from foundation can show variation from the foundation size. Therefore, the actual cell size was measured: using calipers to take the length of 10 cells and obtain an average cell size of those 10 ; this measurement was repeated on each frame five times. Foundation size and actual cell size were both considered in this study.

\subsection{Statistical analyses}

Cell size was compared between treatment groups by performing a Mann-Whitney $U$ test on the average cell sizes of each colony. This test was also used to look at whether the foundation size affected the final comb cell size. $\mathrm{R}$ statistical analysis software (R Core Team 2008) and the LME4 package (Bates et al. 2015) were used to perform general linear models and mixed-effects models to test the effect of actual cell size and foundation base size on the average number of viable female offspring per foundress. Models were fitted by maximum likelihood (Laplace approximation). Foundation size, actual cell size, brood stage, and foundress number for each cell were added as fixed effects; foundress number and brood stage are both known to influence mite reproductive success and offspring estimates (Fuchs and Langenbach 1989; Martin 1995). The donor colony that housed each frame prior to the experiment was set as a random effect to account for between-colony variance. The data from both apiaries (surviving and susceptible) were analyzed together and then split and analyzed separately to examine possible interacting effects between colony type and actual cell/ foundation base size. Similar models were created for the variables of non-reproduction, delayed reproduction, male presence, and infestation rates. Models were adjusted to account for the binomial nature of the data using the logit function. Minimum adequate models were isolated by removing non-significant terms and reducing models to include only parameters that significantly affected variation in the response variable. Dispersion 
parameters were monitored for all models and found to be within a reasonable range.

\section{RESULTS}

The average cell size measured on the combs of the donor colonies did not differ significantly between surviving and susceptible receiver colonies (Mann-Whitney $U=9.00, n_{1}=10 n_{2}=9$, $p>0.05$, two-tailed, surviving mean $=5.29 \pm$ 0.23 , susceptible mean $=5.20 \pm 0.22$ ). Average cell size on frames given to surviving colonies was between 4.92 and $5.53 \mathrm{~mm}$ and average cell size provided to susceptible colonies was between 4.93 and $5.50 \mathrm{~mm}$. Cell sizes on the large foundation were overall significantly larger than those built on the small foundation (Mann-Whitney $U=7.00, n_{1}=10 n_{2}=9, p<0.05$, two-tailed, mean for large $=5.44 \pm 0.06$, mean for small $=$ $5.09 \pm 0.20)$. When foundation size was analyzed, there was no significant difference in the average number of viable female offspring per foundress between the large and small cell bases (Table I, $\chi^{2}=0.69, p=0.405$, mean viable offspring count for large foundation $=1.09 \pm 0.34$, mean viable offspring count for small foundation $=1.10 \pm$ $0.15)$. However, when actual cell size was investigated, it was found that there was a significant interacting effect between cell size and whether the colony was from the surviving or susceptible group (Table I, $n=832, \chi^{2}=5.48, p=0.019$ ). When colony groups were analyzed separately, it was found that in susceptible colonies, small cell size correlated significantly with a reduced number of viable female offspring in cells $(n=410$, $\chi^{2}=4.86, p=0.028$, Figure 1$)$. No significant effect was found in the surviving colonies $(n=$ $422, \chi^{2}=0.64, p=0.423$, Figure 1). In susceptible colonies, frames with a smaller average cell size had higher rates of mite non-reproduction (Figure 2a, Table II, $n=301, \chi^{2}=6.32, p=$ 0.012 ), and delayed reproduction (Figure $2 \mathrm{~b}$, Table II, $n=301, \chi^{2}=5.30, p=0.021$ ). Male mite presence was also lower on frames with a smaller cell size (Figure 2c, Table II, $n=301$, $\left.\chi^{2}=6.61, p=0.010\right)$. Cell size did not yield a significant impact on the levels of infertility (Table II, $\chi^{2}=0.59, p=0.441$ ). None of the binomial parameters were found to be significantly affected by actual cell size in surviving colonies

Table I. Mixed-effects model outputs outlining the effect of foundation size and actual cell size on the viable female offspring count per cell. Models fitted by maximum likelihood. Minimum adequate models were isolated by excluding non-significant terms.

\begin{tabular}{|c|c|c|c|c|c|c|}
\hline Model & $n$ & Independent variable & Dependent variable & $\mathrm{df}$ & $\chi^{2}$ & $p$ value \\
\hline \multirow[t]{5}{*}{ M1 } & \multirow[t]{5}{*}{832} & \multirow{5}{*}{$\begin{array}{l}\text { Number of viable female } \\
\text { offspring per foundress }\end{array}$} & Brood stage & 5 & 17.96 & $0.003 * *$ \\
\hline & & & Foundress number & 1 & 0.59 & 0.441 \\
\hline & & & $\begin{array}{l}\text { Colony type int. } \\
\text { foundation size }\end{array}$ & 1 & 0.00 & 0.998 \\
\hline & & & Foundation size & 1 & 0.69 & 0.405 \\
\hline & & & Colony type & 1 & 8.75 & $0.003 * *$ \\
\hline \multirow[t]{3}{*}{ M2 } & \multirow[t]{3}{*}{832} & \multirow{3}{*}{$\begin{array}{l}\text { Number of viable female } \\
\text { offspring per foundress }\end{array}$} & Brood stage & 5 & 0.69 & $0.003 * *$ \\
\hline & & & Foundress number & 1 & 0.63 & 0.430 \\
\hline & & & Colony type int. cell size & 1 & 5.48 & $0.019 *$ \\
\hline \multirow[t]{3}{*}{ M3 (survivor only) } & \multirow[t]{3}{*}{422} & \multirow{3}{*}{$\begin{array}{l}\text { Number of viable female } \\
\text { offspring per foundress }\end{array}$} & Brood stage & 5 & 9.28 & 0.099 \\
\hline & & & Foundress number & 1 & 0.02 & 0.891 \\
\hline & & & Cell size & 1 & 0.64 & 0.423 \\
\hline \multirow[t]{3}{*}{ M4 (susceptible only) } & \multirow[t]{3}{*}{410} & \multirow{3}{*}{$\begin{array}{l}\text { Number of viable female } \\
\text { offspring per foundress }\end{array}$} & Brood stage & & 22.47 & $<0.001 * *$ \\
\hline & & & Foundress number & & 1.47 & 0.226 \\
\hline & & & Cell size & & 4.86 & $0.028 *$ \\
\hline
\end{tabular}

Note: italic terms with an “*” denote statistical significance 


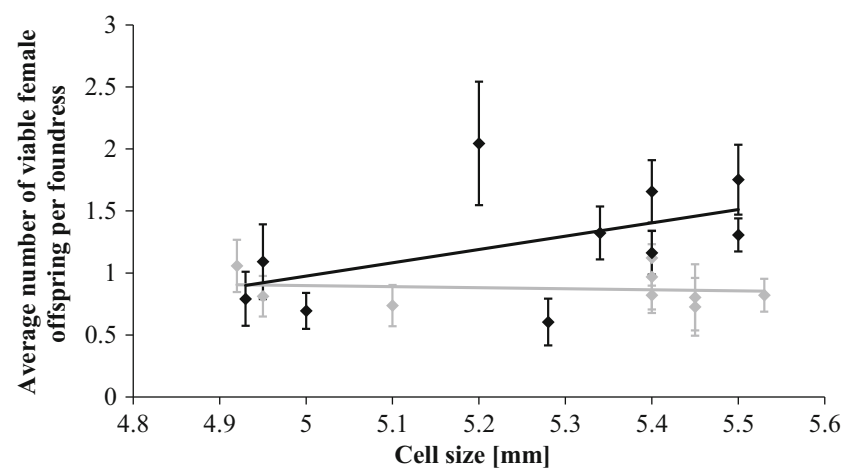

Figure 1 The average number of viable female Varroa destructor mite offspring in each host worker brood cell in relation to the average actual cell diameter per frame in honeybee (Apis mellifera) colonies naturally surviving $V$. destructor infestations (gray) and in susceptible ones (black). No significant correlation could be found in surviving colonies $\left(n=410, \chi^{2}=0.64, p=0.423\right)$. However, in susceptible colonies, there was a significant positive correlation $\left(n=422, \chi^{2}=4.86, p=0.028\right)$.

(Table II). Finally, infestation rates were slightly lower on frames with a smaller average cell size in susceptible receiver colonies (Figure $2 \mathrm{~d}, n=$ $\left.1898, \chi^{2}=260.13, p<0.001\right)$ but no significant pattern could be found in surviving receiver colonies (Figure $2 \mathrm{~d}, n=1529, \chi^{2}=1.98, p=0.160$ ).

\section{DISCUSSION}

Our data support the conclusion that smaller worker brood cell size can significantly contribute to the overall reduced reproductive success of $V$. destructor mites in susceptible colonies and may contribute to lower infestation rates; however, this effect was not significant in surviving colonies known to possess cell recapping as a mitesurviving trait (Oddie et al. 2018). The effect of cell size may be masked by these traits in surviving colonies, or else it is not present. Regardless, a small cell size does not appear to work in tandem with mite resistance traits favored by natural selection in the surviving Norwegian population.

Cell size differences were comparable between surviving and susceptible test colonies and there was an observable distinction between large and small cell size foundation; however, foundation size did not yield significant differences in mite fecundity among surviving or susceptible bees. This is likely due to the fact that some frames built up from small cell foundation actually yielded larger average cell sizes, as was also found by Taylor et al. (2008). The comb-builders in some colonies likely follow the foundation base more accurately than others, making actual cell size a much more reliable measure than foundation base.

When actual cell size was examined in depth, it was found that susceptible colonies did benefit from the small cell size: Cells of smaller average diameter showed slightly lower mite infestation rates as well as a significant increase in delayed reproduction, non-reproduction, and male offspring absence, all factors contributing to a lower mite reproductive success. No effect was found on mite infertility; however, the rates of infertility were very low in general within this study. In contrast, there was no significant effect of cell size in surviving colonies for any measured parameter; therefore, a smaller cell size does not appear to work together with other mechanisms reducing mite reproduction used by naturally-surviving populations (Locke et al. 2012; Oddie et al. 2017). The observation that the infestation rate was affected in the susceptible receiver colonies, but not in the surviving ones, may point to an effect put upon infested cells by the surviving phenotype, though at this point, it can only be speculated as to how this has occurred. If the adult-mediated trait does remove infested cells, it is possible the process is not affected by the size of the cell. The results for susceptible colonies at least align with those found in several previous studies: Message and Gonçalves (1995) uncovered a difference in $V$. destructor infestation rate and number of female mite deutonymphs between 

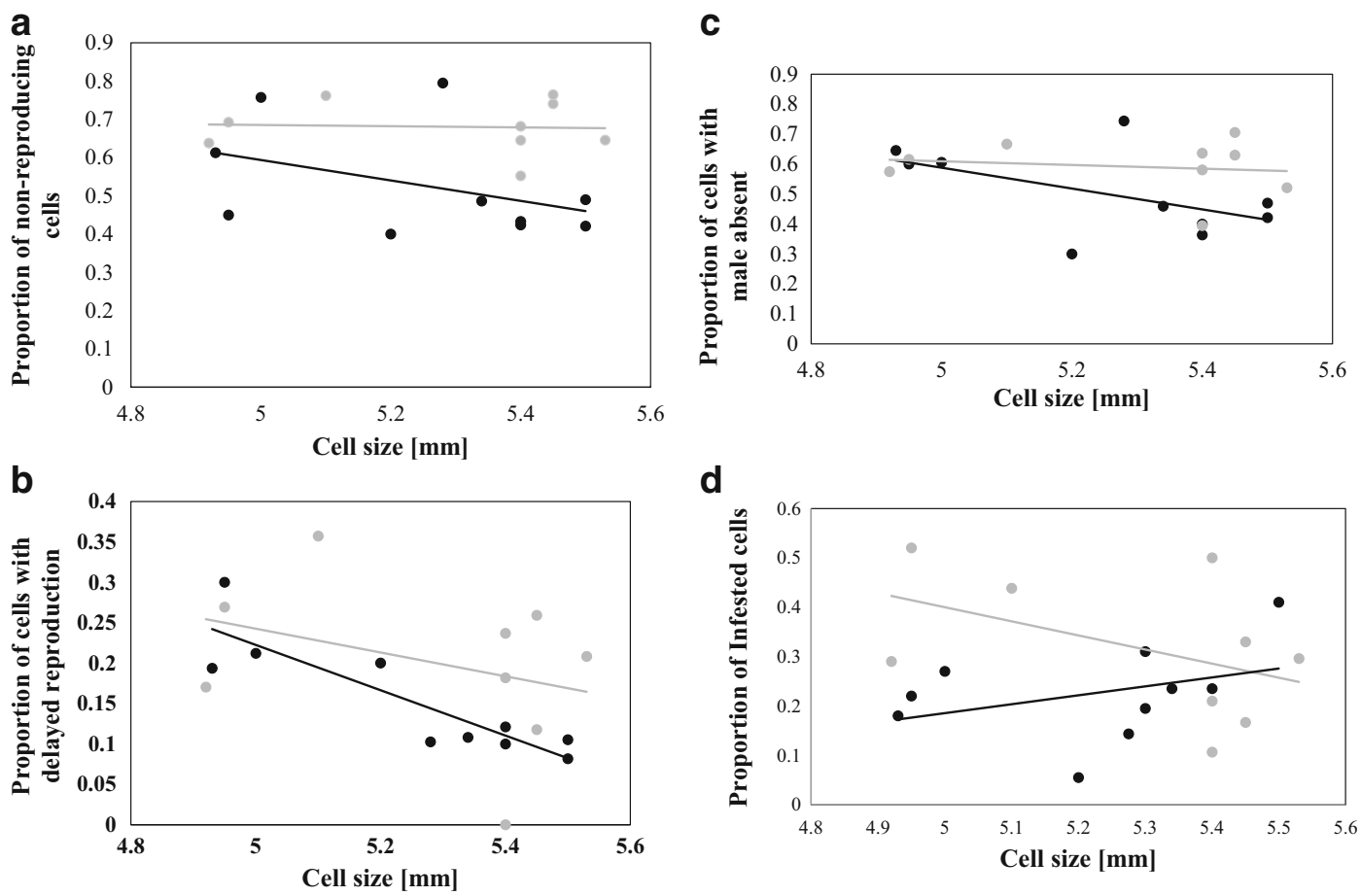

Figure 2 a The proportion of infested honeybee (Apis mellifera) worker brood cells in which Varroa destructor foundresses failed to produce viable female offspring relative to the average cell diameter on the frames in surviving (gray) and susceptible colonies (black). A significant negative correlation was observed in susceptible colonies $(n=$ $301, \chi^{2}=6.32, p=0.012$ ). b The proportion of infested honeybee (Apis mellifera) worker brood cells that displayed a delay in Varroa destructor reproduction and average cell diameter on frames in surviving (gray) and susceptible colonies (black). A significant negative correlation was observed in susceptible colonies $\left(n=301, \chi^{2}=\right.$ 5.30, $p=0.021$ ). c The proportion of infested honeybee (Apis mellifera) worker brood cells without Varroa destructor males and average cell diameter on frames in surviving (gray) and susceptible colonies (black). A significant negative correlation was observed in susceptible colonies $\left(n=301, \chi^{2}=6.61, p=0.010\right)$. $\mathbf{d}$ The proportion of Varroa destructor infested honeybee (Apis mellifera) worker brood in relation to the average diameter of the cells on frames in surviving (gray) and susceptible (black) receiver colonies. A significant positive correlation was found in susceptible colonies $\left(n=1898, \chi^{2}=260.13, p<0.001\right)$.

cells of $4.5-4.6 \mathrm{~mm}$ and those of $4.9-5.1 \mathrm{~mm}$. Maggi et al. (2010) and Piccirillo and De Jong (2003) found differences in the rate of mite infestation between large and small cell sizes. Size ranges in both studies were comparable to the sizes used in this study. Maggi et al. (2010) also investigated mite reproductive rate, but found no significant effect while our dataset uncovered a small but significant reduction. A study in New Zealand (Taylor et al. 2008) did not find a significant influence of cell size on mite reproductive success but found an increase in infestation rate on smaller cell sizes. Berry et al. (2009) found similar results, overall mite populations were higher in colonies reared on the smaller cell size when they compared entire colonies given small or large comb sizes $(4.9 \pm 0.08$ and $5.3 \pm 0.04$ respectively). These varying results provide evidence that there are parameters that have yet to be considered regarding $V$. destructor mite population dynamics in relation to the size of brood cells. It is possible that the different methods and environments of each study are contributing to the mixed results. Changing parameters within a colony such as cell size may change the behavior of the bees to the point where they create unmeasured differences between themselves and a control population. To give an example of this, the study performed by Piccirillo and De Jong (2003) only used bees accustomed to a small cell size for their trials 
Table II. General linear model and mixed-effects model outputs describing the effect of actual cell size on binomial reproductive parameters of Varroa destructor. Models fitted by REML. Minimum adequate models were isolated by excluding non-significant terms.

\begin{tabular}{|c|c|c|c|c|c|c|}
\hline & $n$ & Independent variable & Dependent variable & df & $\chi^{2}$ & $p$ value \\
\hline \multirow[t]{8}{*}{ Susceptible } & \multirow[t]{8}{*}{301} & \multirow[t]{2}{*}{ Male presence } & Cell size & 1 & 6.61 & $0.010 *$ \\
\hline & & & Brood stage & 5 & 6.60 & 0.253 \\
\hline & & \multirow[t]{2}{*}{ Delayed reproduction } & Cell size & & 5.30 & $0.021 *$ \\
\hline & & & Brood stage & & 6.48 & 0.263 \\
\hline & & \multirow[t]{2}{*}{ Non-reproductive } & Cell size & & 6.32 & $0.012 *$ \\
\hline & & & Brood stage & & 4.01 & 0.549 \\
\hline & & \multirow[t]{2}{*}{ Infertile } & Cell size & & 0.59 & 0.441 \\
\hline & & & Brood stage & & 16.63 & $0.005 * *$ \\
\hline \multirow[t]{8}{*}{ Surviving } & \multirow[t]{8}{*}{298} & \multirow[t]{2}{*}{ Male presence } & Cell size & & 0.49 & 0.484 \\
\hline & & & Brood stage & & 4.11 & 0.534 \\
\hline & & \multirow[t]{2}{*}{ Delayed reproduction } & Cell size & & 0.63 & 0.426 \\
\hline & & & Brood stage & & 6.92 & 0.226 \\
\hline & & \multirow[t]{2}{*}{ Non-reproductive } & Cell size & & 0.01 & 0.928 \\
\hline & & & Brood stage & & 3.34 & 0.559 \\
\hline & & \multirow[t]{2}{*}{ Infertile } & Cell size & & 0.08 & 0.775 \\
\hline & & & Brood stage & & 6.85 & 0.233 \\
\hline
\end{tabular}

Note: italic terms with an “*” denote statistical significance

and found higher infestation rates on the larger cell size comb. Taylor et al. (2008) used bees accustomed to the large cell size and found higher infestation rates on smaller comb, and both studies provided their bees with pre-built comb from another source for at least one of the treatment groups. Ellis et al. (2009) used bees accustomed to each cell size; they were kept on for the experiment and found no significant differences in overall mite population. It should then be said that the cell size on which the bees were reared as well as the origin of the comb used should be taken into consideration when analyzing highly variable parameters such as overall colony mite infestation rate and $V$. destructor foundress fecundity. Our study also introduced frames built out by other colonies, yet only two frames were given and kept within the colonies, and only for a single brood cycle; this may not have introduced enough change to elicit a response from the bees.

Our study delved into $V$. destructor mite reproductive parameters in depth, investigating not only viable offspring number, but also proportion of delayed reproduction, non- reproduction, infertility, and male presence, all valuable parameters when considering mite reproductive success (Locke et al. 2012). The fact that we found significant patterns in all of these, save infertility, indicates that cell size does not affect just one parameter largely, but may have small, combined effects in each differing parameter that create an additive difference. Olszewski et al. (2014) found that rearing mite-susceptible bees on foundation size of $4.93 \mathrm{~mm}$ (compared to $5.56 \mathrm{~mm}$ ) increased hygienic behavior performed, though this study could find no significant link to this elevated behavior and the number of immature mites found on the bottom boards. Olszewski et al. (2014) did suggest that small cell size could synergize with hygienic behavior in some populations but not in others depending on the level of hygienic behavior and the bees' adaptability to a smaller cell size. Within-colony variation in our study was large, making it difficult to isolate strong effects, but even between only 10 colonies, a distinct pattern was observed. This study, however, was not long term and could not take into account the 
effect of small cell size on the overall population dynamics of $V$. destructor in the test colonies, so the ability of small cell size to help control $V$. destructor cannot be reported here. To find more robust evidence that small cell size affects mite populations in a practical way, colonies would need to be bred and reared on small cell size and compared year-round with those bees from the same genetic background reared on large cells. Measuring cell diameter for each dissected cell individually instead of taking an average on a frame may also allow for a higher resolution of the collected information. Overall, there are many factors to consider when examining the effect of small cell size on $V$. destructor mite population dynamics. Our study finds evidence that at least in the Nordic ranges of domestic beekeeping, a smaller cell size seems to help reduce the reproductive success of $V$. destructor, but this effect does not seem entirely relevant for bees already known to survive the parasite by means of natural selection. Indeed, A. mellifera populations in temperate European regions naturally display a larger brood cell size compared to African subspecies. This confers an advantage on the African honeybees in terms of flight abilities solely on the grounds of morphometric dimensions due to a better engine to aircraft mass ratio (Hepburn et al. 1999). Nevertheless, natural selection has favored larger cell sizes in the temperate regions. This suggests that surviving colder temperatures may be involved. In colder climates, many species adhere to Bergmann's rule (Bergmann 1847), displaying a trend of larger body sizes at higher latitudes (Cushman et al. 1993; Olson et al. 2009), as this is a better adaptation to tolerate low temperatures. Small cell size and its potential to reduce the sizes of worker bees (McMullan and Brown 2006) may then prove a detriment in the long run to populations in higher latitudes, and though it may produce an effect on $V$. destructor, the overall reduction in competitive ability may render the effect negligible regarding colony survival. Small cell size, though potentially useful in aiding the management of parasites, may not be the key factor in achieving treatment-free, mite-surviving bees in temperate climates.

\section{ACKNOWLEDGMENTS}

We are grateful to the local beekeepers that let us carry out these experiments in their apiaries.

\section{AUTHOR CONTRIBUTIONS}

P.N., B.D. \& M.O. conceived and designed experiments; M.O. collected data; and performed analysis; P.N. \& M.O. wrote the paper, all authors revised it. All authors approved the final manuscript.Funding information

Financial support was granted to P.N. by the Ricola Foundation-Nature and Culture and the Vinetum foundation. Financial support was granted to B.D. by the Norwegian Research Council, grant no. 234193.

\section{OPEN ACCESS}

This article is distributed under the terms of the Creative Commons Attribution 4.0 International License (http://creativecommons.org/licenses/by/4.0/), which permits unrestricted use, distribution, and reproduction in any medium, provided you give appropriate credit to the original author(s) and the source, provide a link to the Creative Commons license, and indicate if changes were made.

Taille des cellules et infestation par les acariens Varroa destructor chez les colonies d'abeilles (Apis mellifera) sensibles et naturellement survivantes

Apis mellifera / taille de la cellule / abeille mellifère / Varroa destructor

Brutzellgrösse und Befall durch Varroa destructor Milben in anfälligen und natürlich überlebenden

Apis mellifera / Zellgrösse / Honigbiene / Varroa destructor

\section{REFERENCES}

Bates, D., Maechler, M., Bolker, B., Walker, S. (2015). Fitting Linear Mixed-Effects Models Using lme4. J. Stat. Softw. 67 (1), 1-48. https://doi.org/10.18637/jss.v067.i01. 
Bergmann, K. G. L. C. (1847) Über die Verhältnisse der Wärmeokönomie der Tiere zu ihrer Grösse. Göttinger Stud. 3, 595-708.

Berry, J. A., Owens, W. B., Delaplane, K. S. (2009). Smallcell comb foundation does not impede Varroa mite population growth in honey bee colonies. Apidologie 41 (1), 40-44.

Chen, Y., Evans, J., Feldlaufer, M. (2006). Horizontal and vertical transmission of viruses in the honey bee, Apis mellifera. J. Invert. Pathol. 92 (3), 152-159.

Corrêa-Marques, M. H., Medina, L. M., Martin, S. J., De Jong, D. (2003). Comparing data on the reproduction of Varroa destructor. Genet. Mol. Res. 2 (1), 1-6.

Cushman, J. H., Lawton, J. H., \& Manly, B. F. (1993). Latitudinal patterns in European ant assemblages: variation in species richness and body size. Oecologia, 95(1), 30-37.

Dahle, B. (2010). The role of Varroa destructor for honey bee colony losses in Norway. J. Apic. Res. 49 (1), 124-125.

Dainat, B., Evans, J. D., Chen, Y. P., Gauthier, L., Neumann, P. (2012). Dead or alive: deformed wing virus and Varroa destructor reduce the life span of winter honeybees. Appl. Environ. Microbiol. 78(4), 981-987.

De Jong D., Morse R. A., (1988) Utilization of raised brood cells of the honey bee, Apis mellifera (Hymenoptera: Apidae), by the mite Varroa jacobsoni (Acarina: Varroidae). Entomol. Gen. 14(2), 103-106.

De Ruijter, A., Calis, J. (1988). Distribution of Varroa jacobsoni female mites in honey bee worker brood cells of normal and manipulated depth (Acarina: Varroidae). Entomol. Gen. 14(2), 107-109.

Dietemann, V., Nazzi, F., Martin, S. J., Anderson, D. L., Locke, B.et al. (2012). Standard methods for varroa research. J. Apic. Res. 52 (1), 1-54.

Ellis, A. M., Hayes, G. W., Ellis, J. D. (2009). The efficacy of small cell foundation as a varroa mite (Varroa destructor) control. Exp. Appl. Acarol. 47 (4), 311-316.

Fries, I., Imdorf, A., Rosenkranz, P. (2006) Survival of mite infested (Varroa destructor) honey bee (Apis mellifera) colonies in a Nordic climate. Apidologie 37 (5), 564-570.

Fuchs, S., Langenbach, K. (1989). Multiple infestation of Apis mellifera L. brood cells and reproduction in Varroa jacobsoni Oud. Apidologie 20 (3), 257-266.

Genersch, E., Von Der Ohe, W., Kaatz, H., Schroeder, A., Otten, C., Büchler, R., Berg, S., Ritter, W., Mühlen, W., Gisder, S. et al. (2010) The German bee monitoring project: a long-term study to understand periodically high winter losses of honey bee colonies. Apidologie 41 (3), 332-52.

Harris, J. W., Danka, R. G., Villa, J. D. (2010). Honey bees (Hymenoptera: Apidae) with the trait of varroa sensitive hygiene remove brood with all reproductive stages of varroa mites (Mesostigmata: Varroidae). Ann. Entomol. Soc. Am. 103 (2), 146-152.

Hepburn, H., Radloff, S., Fuchs, S. (1999). Flight machinery dimensions of honeybees, Apis mellifera . J. Comp. Physiol. B. 169 (107), https://doi.org/10.1007 /s003600050200
Le Conte, Y., De Vaublanc, G., Crauser, D., Jeanne, F., Rousselle, J. C., Bécard, J. (2007). Honey bee colonies that have survived Varroa destructor. Apidologie 38 (6), 566-572.

Locke, B. (2016) Natural Varroa mite-surviving Apis mellifera honeybee populations. Apidologie 47 (3), 467-482.

Locke, B., Conte, Y. L., Crauser, D., Fries, I. (2012). Host adaptations reduce the reproductive success of Varroa destructor in two distinct European honey bee populations. Ecol. Evol. 2 (6), 1144-1150.

Locke, B., Forsgren, E., de Miranda, J. R. (2014). Increased tolerance and resistance to virus infections: a possible factor in the survival of Varroa destructor-resistant honey bees (Apis mellifera). PLoS ONE, 9(6), e99998. https://doi.org/10.1371 /journal.pone.0099998.

Maggi, M., Damiani, N., Ruffinengo, S., De Jong, D., Principal, J., Eguaras, M. (2010). Brood cell size of Apis mellifera modifies the reproductive behavior of Varroa destructor. Exp. Appl. Acarol. 50 (3), 269-279.

Martin, S. J. (1995). Ontogenesis of the mite Varroa jacobsoni Oud. in drone brood of the honeybee Apis mellifera L. under natural conditions. Exp. Appl. Acarol. 19(4), 199-210.

Martin, S. J. (2001). The role of Varroa and viral pathogens in the collapse of honeybee colonies: a modelling approach. Journal of Applied Ecology, 38(5), 1082-1093.

McMullan, J. B., \& Brown, M. J. (2006). The influence of small-cell brood combs on the morphometry of honeybees (Apis mellifera ). Apidologie 37 (6), 665-672.

Message, D., Gonçalves, L. S. (1995). Effect of the size of worker brood cells of Africanized honey bees on infestation and reproduction of the ectoparasitic mite Varroa jacobsoni Oud. Apidologie 26(5), 381-386.

Mikheyev, A. S., Tin, M. M., Arora, J., Seeley, T. D. (2015). Museum samples reveal rapid evolution by wild honey bees exposed to a novel parasite. Nat. Commun. 7199, https://doi.org/10.1038/ncomms8991.

Neumann, P., Blacquière, T. (2017). The Darwin cure for apiculture? Natural selection and managed honeybee health. Evol. appl. 10(3), 226-230.

Neumann, P., Carreck, N. L. (2010). Honey bee colony losses. J. Apic. Res. 49 (1), 1-6.

Oddie, M. A. Y., Dahle, B., Neumann, P. (2017). Norwegian honey bees surviving Varroa destructor mite infestations by means of natural selection. PeerJ 5, e3956, https://doi.org/10.7717/peerj.3956.

Oddie, M. A. Y., Büchler, R., Dahle, B., Kovacic, M., Le Conte, Locke, B., de Miranda, J., Mondet, F. , Neumann, P. (2018). Rapid parallel evolution overcomes global honey bee parasite. Sci. Rep. 8(1), 7704.

Olson, V. A., Davies, R. G., Orme, C. D. L., Thomas, G. H., Meiri, S. et al. (2009). Global biogeography and ecology of body size in birds. Ecol. Lett. 12 (3), 249-259.

Olszewski, K., Borsuk, G., Paleolog, J., Strachecka, A., Bajda, M. (2014). Hygienic behaviour of colonies kept on small-cell combs. Med. Weter. 70(12), 774-776. 
Piccirillo, G. A., De Jong, D. (2003). The influence of brood comb cell size on the reproductive behavior of the ectoparasitic mite Varroa destructor in Africanized honey bee colonies. Genet. Mol. Res. 2 (1), 36-42.

R Development Core Team (2008). R: A language and environment for statistical computing. R Foundation for Statistical Computing, Vienna, Austria. ISBN 3900051-07-0, http://www.r-project.org.

Rinderer, T. E., de Guzman, L. I., Delatte, G. T., Stelzer, J. A., Lancaster, V. A., Kuznetsov, V., Beamann, L., Watts, R., Harris, J. W. (2001). Resistance to the parasitic mite Varroa destructor in honey bees from fareastern Russia. Apidologie 32 (4), 381-394.

Rosenkranz, P., Aumeier, P., \& Ziegelmann, B. (2010). Biology and control of Varroa destructor. J. Invert. Pathol. 103, 96-119.

Salvy, M., Martin, C., Bagneres, A. G., Provost, E., Roux, M., Le Conte, Y., Clement, J. L. (2001). Modifications of the cuticular hydrocarbon profile of Apis mellifera worker bees in the presence of the ectoparasitic mite Varroa jacobsoni in brood cells. Parasitol. $122(2)$, 145-159.

Sammataro, D., Gerson, U., Needham, G. (2000). Parasitic mites of honey bees: life history, implications, and impact. Ann. Rev. Entomol. 45 (1), 519-548.

Seeley, T. D. (2007). Honey bees of the Arnot Forest: a population of feral colonies persisting with Varroa destructor in the northeastern United States. Apidologie 38(1), 19-29.

Taylor, M. A., Goodwin, R. M., McBrydie, H. M., Cox, H. M. (2008). The effect of honey bee worker brood cell size on Varroa destructor infestation and reproduction. J. Apic. Res. 47 (4), 239-242.

VanEngelsdorp, D., Hayes Jr, J., Underwood, R. M., Caron, D., Pettis, J. (2011). A survey of managed honey bee colony losses in the USA, fall 2009 to winter 2010. J. Apic. Res. 50 (1), 1-10. 